\title{
CHARACTERISATION AND OSL DATING OF AN ANCIENT BRICK WELL AT PATTARAIPERUMBUDUR, TAMIL NADU, INDIA
}

\author{
KARAKTERIZACIJA IN DATIRANJE STARODAVNEGA \\ OPEČNATEGA VODNJAKA V PATTARAIPERUMBUDURU, TAMIL \\ NADU, INDIJA
}

\author{
Alby Sara Mathew ${ }^{1}$, Minnoo Grasa Abraham ${ }^{1}$, Thirumalini Selvaraj ${ }^{1 *}$, \\ Baskar Jaganathan ${ }^{2}$ \\ ${ }^{1}$ School of Civil Engineering, Vellore Institute of Technology, Katpadi Road, VIT campus, Vellore, Tamil Nadu 632014, India \\ 2Department of Archaeology, Tamil Nadu 602023, India \\ Prejem rokopisa - received: 2020-06-22; sprejem za objavo - accepted for publication: 2020-07-15
}

doi:10.17222/mit.2020.042

\begin{abstract}
This paper is about characterizing a brick sample obtained from the brick well at Pattaraiperumbudur, a recently excavated site in Tiruvallur, Tamil Nadu. The petro-archaeometry studies of this site included the findings about its elemental constitution, mineralogical composition, thermal changes and physical properties. The elemental constitution was determined using an XRF test, while the mineral composition was found with the help of XRD and FT-IR, showing the chemical bonding at various peaks. A material can undergo different thermal reactions at various temperatures and the effect of temperature on the sample was screened through a TG-DTA analysis. Optical microscopy $(\mathrm{OM})$ is one of the important tests used in petro-archaeological studies, confirming the XRD results. The morphology of the sample was studied with the aid of FE-SEM, which provided an idea about the porous structure and elemental composition. Physical tests of water absorption, porosity and bulk density provided information on the durability of the brick sample. The combined results of TGA and XRD suggest that the firing of the bricks had taken place below $950^{\circ} \mathrm{C}$ in an oxidising atmosphere. The chemical composition reveals that the clay contains a low amount of $\mathrm{CaO}$ and the flux concentration is greater than $9 \%$, indicating low refractory. The extracted brick samples were subjected to carbon dating using optically stimulated luminescence (OSL) that found them to be 2100 years old. 3D rendering of the well was created with the help of the H-BIM tool.

Keywords: mineral characterisation, microstructural analysis, OSL dating
\end{abstract}

V članku avtorji opisujejo karakterizacijo vzorca opeke, vzetega iz opečnatega vodnjaka v Pattaraiperumbuduru, kjer so nedavno izvedli geološka izkopavanja v Tiruvallurju, Tamil Nadu, v Indiji. Petro-arheološke študije tega nahajališča obsegajo raziskovanje osnovne kemijske zgradbe, mineraloške sestave, termalnih sprememb in fizikalnih lastnosti izkopanih vzorcev. Kemijsko sestavo vzorcev so določili z rentgensko fluorescenco (XRF), medtem ko so mineraloško sestavo določili z rentgensko difrakcijo (XRD) in Fourierjevo transformacijsko infrardečo spektroskopijo (FT-IR). Material med segrevanjem in ohlajanjem lahko doživi vrsto sprememb. Te so opazovali s pomočjo termo-gravimetrije (TG) in diferencialne termične analize (DTA). S pomočjo optične mikroskopije $(\mathrm{OM})$, ki je ena od osnovnih metod petro-arheoloških raziskav, so potrdili rezultate dobljene $\mathrm{z}$ XRD. Morfologijo vzorcev so študirali z vrstično elektronsko mikroskopijo na poljsko emisijo (FE-SEM), ki lahko pomaga pri opisu porozne strukture in kemijske sestave. Fizikalne preiskave, kot so na primer določitev absorpcije vode, poroznosti in volumske gostote, podajajo informacijo o dobi trajanja oz. starosti vzorcev opeke. S kombiniranjem rezultatov TGA in XRD so avtorji ugotovili, da je bila opeka žgana pod $950{ }^{\circ} \mathrm{C}$ v oksidacijski atmosferi. Kemijska analiza je pokazala, da glina vsebuje majhno vsebnost $\mathrm{CaO}$ in da je vsebnost talil večja kot $9 \%$, kar kaže na to, da ima analizirana opeka slabo ognjevzdržnost. Izkopani vzorci opeke so bili datirani z ogljikom oz. uporabo optično simulirane luminescence (OSL). Datiranje je pokazalo, da so vzorci stari 2100 let. 3-D prikaz vodnjaka so obnovili in predstavili s pomočjo programskega orodja H-BIM (angl.; Heritage Building Information Modeling).

Ključne besede: mineraloška karakterizacija, mikrostrukturna analiza, datiranje z optično simulirano luminescenco (OSL).

\section{INTRODUCTION}

This paper highlights important correlations between civil-engineering, archaeological and architectural values. The civil-engineering aspect involves the study of the materials and production technology adopted during a construction; the archaeological aspect involves the investigation of the period, in which the structure was built; the architectural aspect tells us about the creative ideas of ancient people. When we look into our past, we

*Corresponding author's e-mail:

thirumalini.selvaraj@vit.ac.in (Thirumalini Selvaraj) find many vital structures and monuments, which had been constructed in the early centuries. The technology used then is still a mystery to the present generation. So, it is of utmost importance to determine the methods and techniques used in our country for the construction of these ancient heritage structures. This study includes a characterisation of the building materials. The characterisation process includes mineralogical, elemental and textural detailing of the sample. ${ }^{1}$ This kind of study is termed as petro-archaeometry.

Bricks are one of the most ancient building materials known to us. The aesthetic aspect of brick work has 
gained a lot of consideration over the years. The historic relevance of these ancient structures or monuments is of utmost importance not only for the analyses and preservation process but also for understanding the technologies used by the ancient people; besides, these structures connect the ancient and modern era. The knowledge of the raw materials used in construction process is very important for the restoration of ancient structures. ${ }^{2}$

The study of ancient structures has always been crucial in our research area. ${ }^{4}$ The wide research in this area helps us understand the evolution of construction technologies and the living style of our ancestors. ${ }^{4}$ The potentials of the study of heritage science are enhanced with the help of petro-archaeometric studies, analysing the chemical compositions of the materials used for the construction of these structures. ${ }^{3,4}$

Pattaraiperumbudur is an archaeologically important site excavated in the village of Tiruvallur, Tamil Nadu. Numerous archaeological artefacts from the prehistoric period to the early historic period were found during the excavation. These include pottery, stone tools and bricks, which represent the Palaeolithic culture of the site. Apart from the stone-age tools, the remnants of the iron-age culture were also identified. During the excavation, a brick well was found at a depth of $2.85 \mathrm{~m}$. Based on a visual inspection, a sample brick seemed less porous and comparatively larger than the present bricks, rectangular and orange-red in appearance. No salt efflorescence that reduces a major stress caused to bricks was observed. ${ }^{2}$

In order to find the technologies used in the manufacturing of building materials, the characterisation of the brick sample was important..$^{5}$ The characterisation included the study of the physical properties, mineral composition, thermal reactions during the baking process and
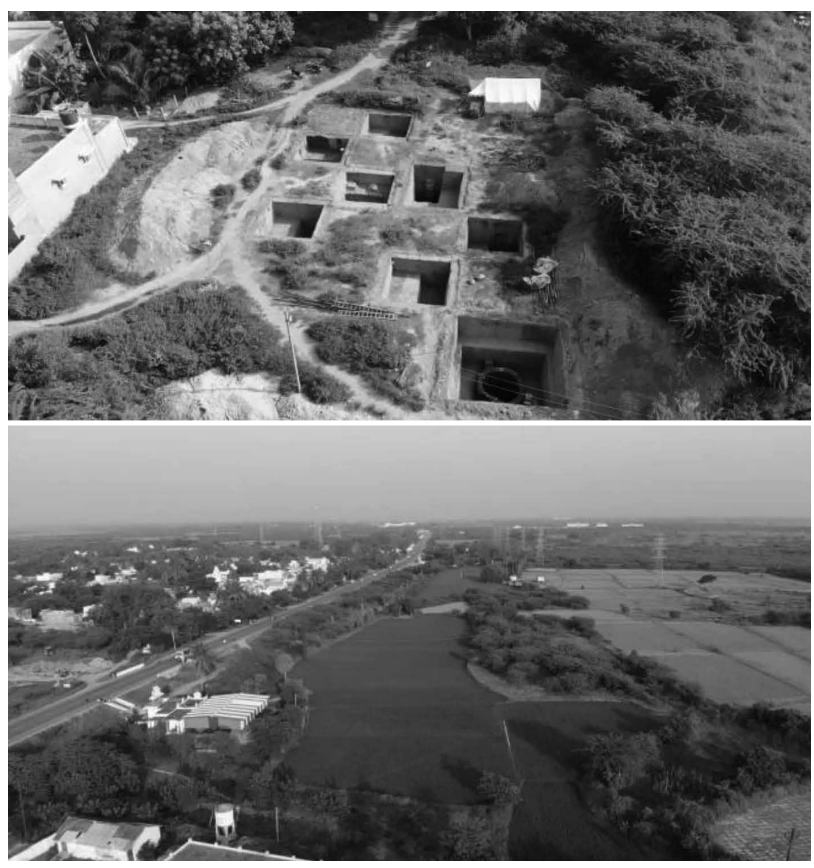

Figure 1: Ariel view of the Pattaraiperumbudur excavated site also the microstructure of the material. ${ }^{2,3}$ The physical properties studied were the water absorption, porosity and bulk density. ${ }^{10}$ The water absorption is proportional with the porosity. The chemical composition of the sample was determined with XRF. With the help of the XRF data, the type of clay was determined with respect to whether it was a calcareous or non-calcareous substance, ${ }^{6}$ while a TG-DTA analysis helped us understand the firing temperatures and weight loss due to the thermal activity. ${ }^{2,6}$ Mineralogical analyses were performed with the help of X-ray diffraction. ${ }^{2,3,4}$ Petrographic and microstructural studies were carried out with the help of optical microscopy (OM). The texture level of the vitrification and the pore size were evaluated with the help of FE-SEM. ${ }^{1,8}$ EDS gave the elemental composition for a particular region of the sample. ${ }^{3,14}$ FT-IR helped us study chemical reactions such as decomposition, dihydroxylation and deconvolutions associated with heating. ${ }^{9,10,13}$ OSL dating gave the information about the age of the sample. ${ }^{21}$ Dating can be done using two methods, thermoluminescence and optical luminescence. In this project, optically stimulated luminescence was carried out. Some minerals are capable of storing a small amount of energy derived from the radioactive elements such as uranium, thorium and potassium when they are exposed to radioactive decay. Later, the ejected electrons and holes recombine with the opposite charges when the light is stimulated and thus luminescence of the sample is formed. ${ }^{23}$ We also used the terms equivalent dose, which is the amount of energy absorbed by a buried sample, and dose rate, which is the measurement of the energy absorbed every year from the radiation present in
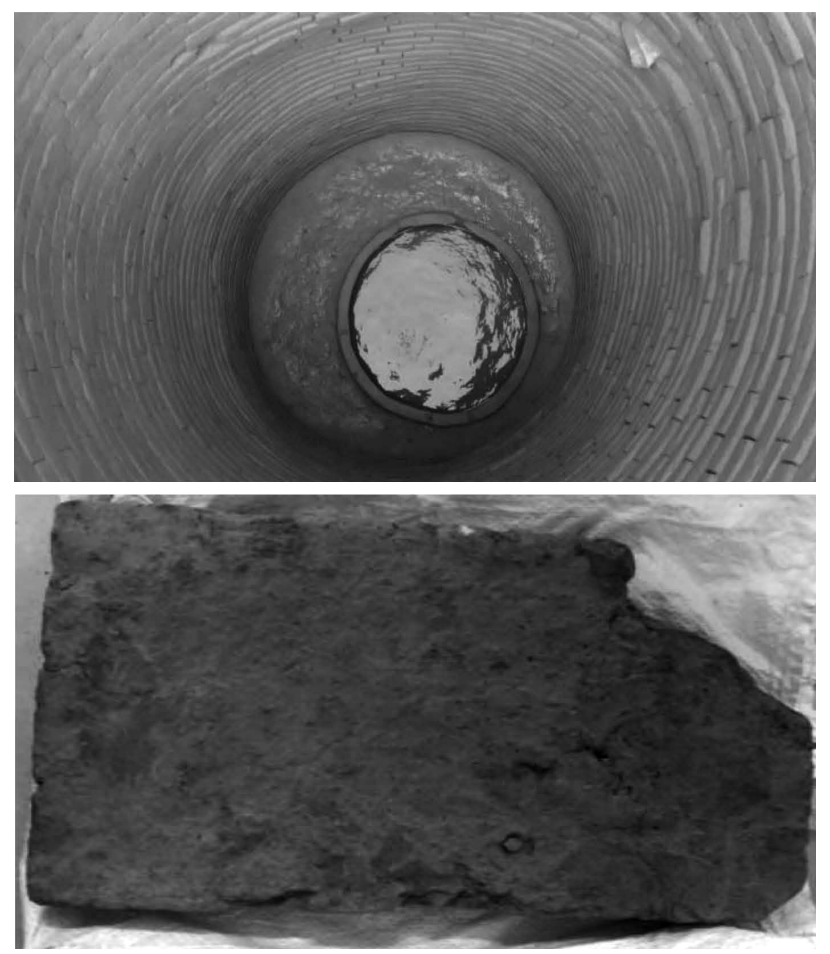

Figure 2: Brick well and the brick sample 
the surrounding environment. Dating techniques were mainly used by the department of archaeology for determining the era of the construction of the remains obtained from the excavation site. Figure 1 shows the ariel view of the site.

\section{MATERIALS AND METHOD}

\subsection{Collection of samples}

The site of Pattaraiperumbudur contributes significantly towards the knowledge about ancient settlements. The site lies on the eastern bank of the Kosathalaiyar River. A number of sites on the bank of the Kosathalaiyar River have a great significance for the Indian Palaeolithic archaeology. An archaeological team carried out an excavation between May and September 2018. The sampling of well was done under the guidance of the officials from the Department of Archaeology, Tamil Nadu. A brick sample was removed from the top course. Many trenches with sizes of $10 \mathrm{~m} \times 10 \mathrm{~m}$ and $4.25 \mathrm{~m} \times$ $4.25 \mathrm{~m}$ were dug during the excavation at the Pattaraiperumbudur site. The brick well was found in trench B1 at a depth of $2.85 \mathrm{~m}$. From the preliminary examination of the site, information regarding the size, depth and nature of the soil was obtained. The depth from the first course to last course of the well is about 3 . $91 \mathrm{~m}$. The exterior and interior diameters of the well are $2.60 \mathrm{~m}$ and $2.20 \mathrm{~m}$. The number of brick courses is 52 and each course consists of 32 bricks. The average size of a brick is $24 \mathrm{~cm} \times 24 \mathrm{~cm} \times 7 \mathrm{~cm}$. Figure 2 shows the well and the brick.

\subsection{Optical microscopy}

The mineral composition was observed using a Zeiss optical microscope. Thin polished sections required for optical microscopy were prepared at Chennai, Tamil Nadu. Petrographic sections were prepared by cutting a slice of the sample with a thickness of $0.03 \mathrm{~mm}$, which was then attached to a glass slide with epoxy resin and covered with a glass slip. This slide is examined under a polarising microscope.

\section{$2.3 X$-ray diffraction (XRD)}

A Siemens D500 Advance diffractometer using $\mathrm{Cu}-K$ radiation, equipped with a $\mathrm{NaI}(\mathrm{Tl})$ scintillation detector was used for the XRD analysis. Samples of about 5-10 $\mathrm{mg}$ were finely ground, sieved through a 45 -micron sieve and used for the analysis. XRD provided the mineral composition of the brick sample. The Xpert high-score software was used to identify the mineralogical composition.

\subsection{Fourier transform infrared spectroscopy (FT-IR)}

An IR Affinity-1 using software IR Solution 1.60 with a resolution of $0.5-16 \mathrm{~cm}^{-1}$ was used for the FT-IR spectroscopy. The instrument has a precision of $\pm 5 \mathrm{~cm}^{-1}$. This investigation was done using the $\mathrm{KBr}$ pellet technique, whose wave number ranged from $4000 \mathrm{~cm}^{-1}$ to $400 \mathrm{~cm}^{-1}$ and also by mixing the powdered samples with $\mathrm{KBr}$ in the 1:20 weight proportion. A sample of about 5-10 mg was required for the analysis; infrared radiation was applied to it, some of which was absorbed by the sample while some passed through it. Each molecular element has a different infrared pattern; thus, functional organic and inorganic groups can be identified.

\subsection{Field-emission scanning electron microscopy (FE-SEM)}

A morphological study of the samples was carried out using a Thermo Fisher FEI QUANTA 250 FEG equipped with a Schottky field-emission electron gun as the electron source. It provides a high resolution of 1.2 $\mathrm{nm}$ at $30 \mathrm{kV}$ and high vacuum in an operating voltage range of 5-30 kV. The sample used for the analysis was sputter coated with a very thin gold layer, resisting the charging and the sample was magnified in a range of 5-10.000 kX with a spot energy-dispersive spectrometer (EDS) to evaluate the elemental composition of the sample.

\subsection{X-ray flourescence $(X R F)$}

The elemental bulk compositions of the finely ground $<45 \mu \mathrm{m}$ powder as lime-paste reproductions in $w / \%$ oxides were obtained using a JEOL JS83201Z X-ray fluorescence spectrometer. About $10 \mathrm{~g}$ of powder was inserted into the sample tube of a 3628 Bench-Press Spex Cretiprep disc press machine to form a thin sample plate at a pressure of 20 tons in $2 \mathrm{~min}$. The resulting sample disc was placed into the sample holder of the X-ray fluorescence spectrometer and the analysis of each oxide was performed within an error of $0.01 \mathrm{w} / \%$.

\subsection{Thermogravimetric analysis (TGA)}

TG-DTA analyses were carried out using a SDT Q600. It has a heating rate of $5-20{ }^{\circ} \mathrm{C} /$ minute. Samples can be heated in nitrogen up to $1200{ }^{\circ} \mathrm{C}$. Dried powdered samples of 5-10 mg were used for the analysis, during which the rate of change in the weight of a sample as a function of temperature or time was measured in a controlled atmosphere.

\subsection{Optically stimulated luminescence (OSL)}

The lab was equipped with a TL-DA-15 luminescence reader and alpha counter to determine the uranium and thorium contents in a sample. The sample preparation was done under subdued-red-light conditions. Blue or green light was used when dealing with quartz and infrared light was used for feldspar. The single-aliquot protocol (SAR) was followed. In the preliminary treatment, first the sun-exposed layers were filed off and crushed in 

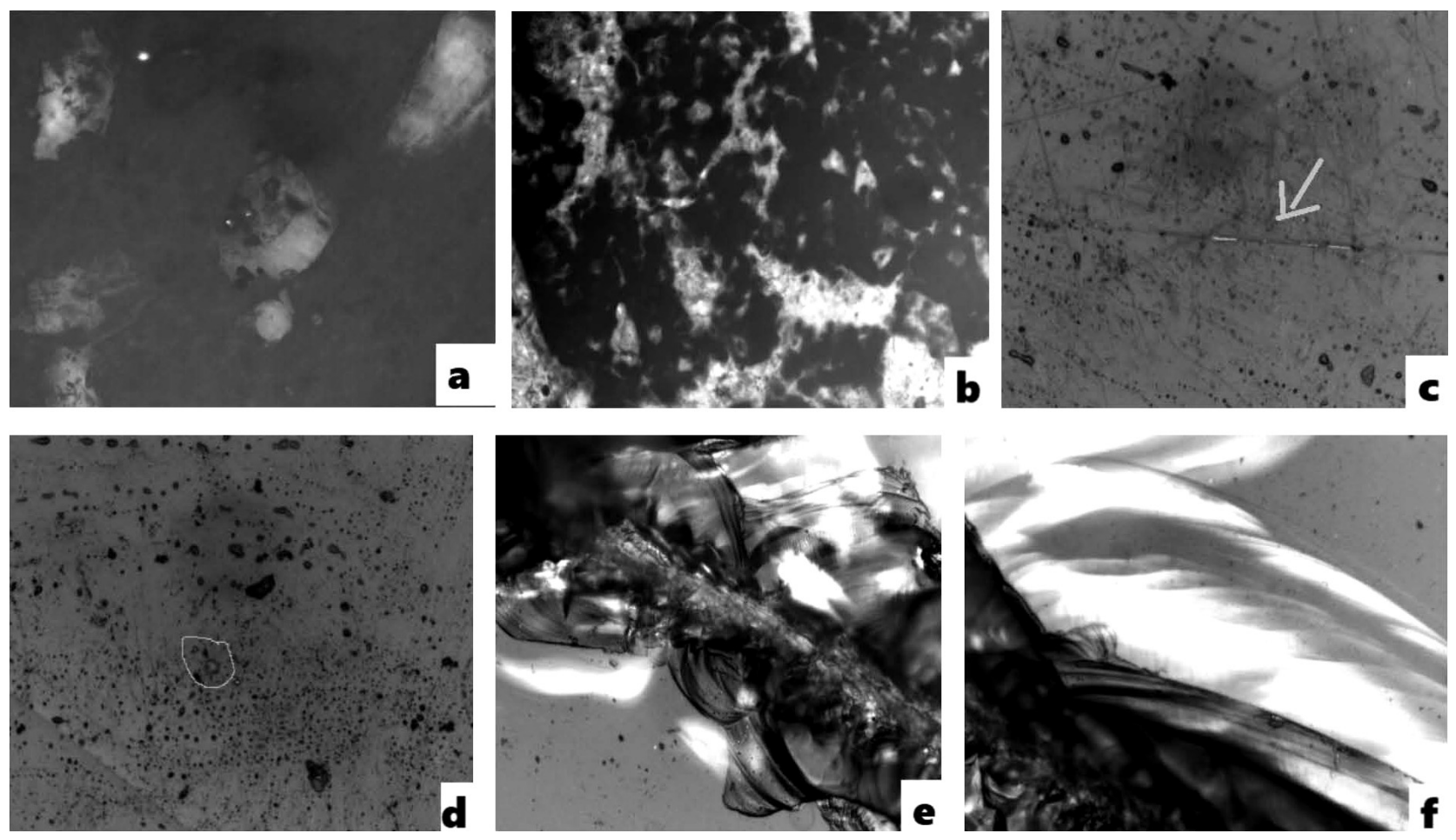

Figure 3: Optical microscopy: a, b) quartz; c) feldspar; e, f) boromuscovite

a beaker where the removal of carbonates and organics was done with chemical solutions. Density separation was done to separate quartz and feldspar; etching was also done to remove the alpha skin. The preliminary treated sample was then fixed to the stainless disc using silicon spray. About 35 discs were prepared for each sample and run for the test dose. The equivalent dose was calculated using Duller's Analyst software.

Grun's software was used for the age estimation.

Age of the sample $=$ equivalent dose/annual dose rate

\subsection{Mechanical and physical properties}

The mechanical property was determined with the compression test performed on extracted samples, while the physical tests determining the water absorption, porosity and bulk density were carried out in accordance with IS 3495 (Part 1-4): 1992. The compression testing was carried out at a loading rate of $1.28 \mathrm{KN} / \mathrm{sec}$ [IS 3495 PART 1: 1992].

Water absorption (\%) was calculated using formula $\left[M_{2}-M_{1}\right] \times 100 / M_{1}$.

Porosity $(\%)=\left[\left(M_{2}-M_{1}\right) /\left(M_{2}-M_{3}\right)\right] \times 100$

Bulk density $=\left[M_{1} /\left(M_{3}-M_{2}\right)\right] \times 10^{3}$,

where

$M_{1}=$ mass of an oven-dried specimen;

$M_{2}=$ mass of a saturated specimen;

$M_{3}=$ hydrostatic mass.

Compressive strength $=$ maximum load at failure/net area of faces under compression.

\subsection{Structural drawing}

3D modelling was done to get the accurate dimensions and a perfect model of the well. It was done with the help of the H-BIM tool. The images required for the modelling were captured with a Kinect sensor and the Context Capture software was used for the modelling.

\section{RESULTS AND DISCUSSION}

\subsection{Optical microscopy}

The thin sections were examined with a polarising microscope and the pictures included in Figure 3 were

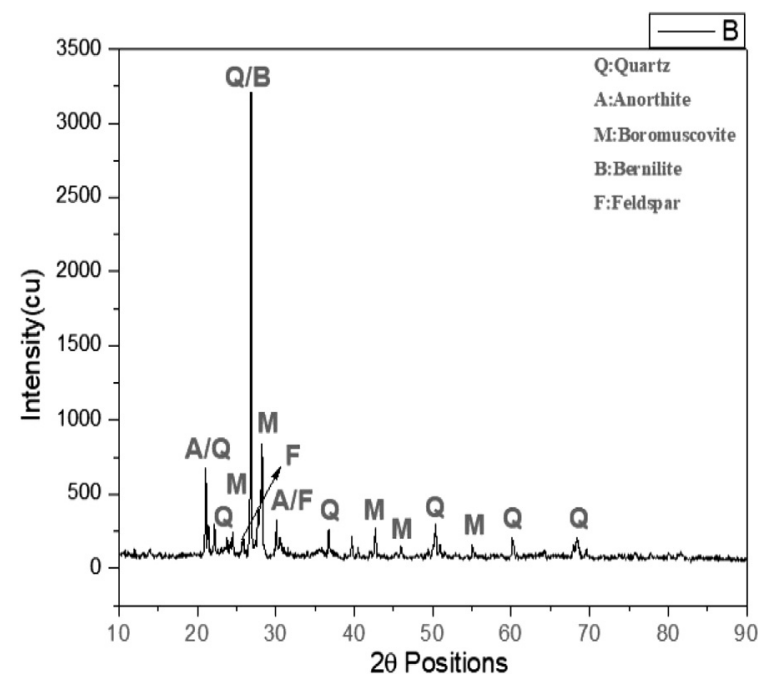

Figure 4: XRD of the brick sample 


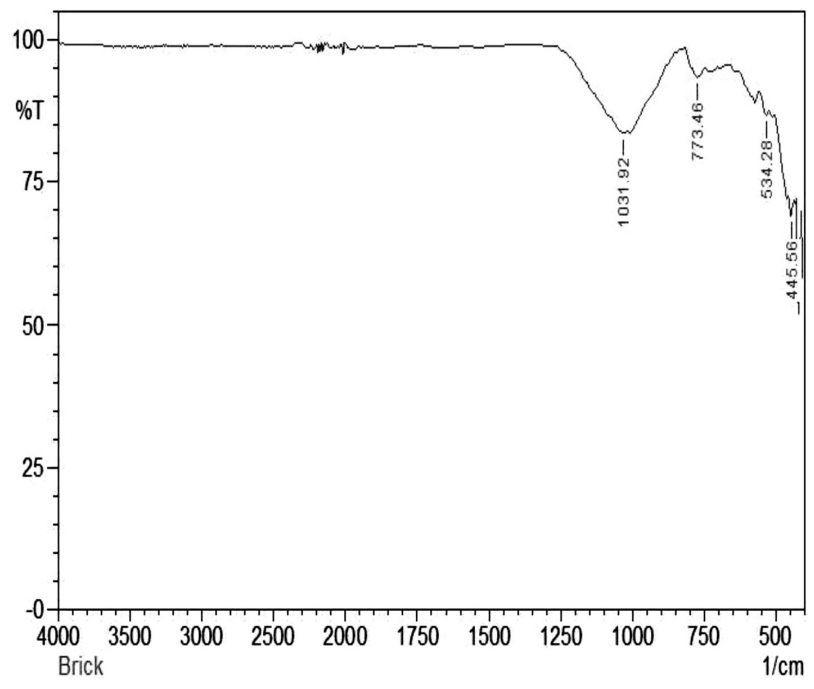

Figure 5: FT-IR peaks of the brick

obtained. In the polarized-light microscope, the bending of planar morphological elements such as rational crystal or cleavage indicate plastic crystal deformation. ${ }^{25}$ From these images, the presence of quartz, feldspar, hematite and boromuscovite can be identified. ${ }^{25}$

\subsection{XRD}

The XRD plots were recorded in a $2 \theta$ range of 10-90. The XRD analysis of the brick sample in Figure 4 indicates the presence of quartz, boromuscovite, berlinite, anorthite and feldspar. It also indicates the phase transformation of calcite into anorthite at different sintering temperatures. ${ }^{10}$ The XRD results are consistent with the FT-IR analysis which shows broadening peaks at $1100-1000 \mathrm{~cm}^{-1}$, referring to the amorphization reaction.

\subsection{FT-IR}

Figure 5 depicts the FT-IR spectra of the brick sample. The deconvolution of the peak range between $2450-2000 \mathrm{~cm}^{-1}$ and $1200-800 \mathrm{~cm}^{-1}$ indicates the exposure of the brick sample to different firing temperatures. ${ }^{9}$ The broad absorption band at $1031.92 \mathrm{~cm}^{-1}$ is of an asymmetric $\mathrm{Si}-\mathrm{O}$ stretching followed by a strong absorp- tion band at $445.56 \mathrm{~cm}^{-1}$, also indicating the presence of quartz. ${ }^{9,10}$ The highly sensitive carbonate band, which normally shows at around $1400 \mathrm{~cm}^{-1}$ for a sintered sample was not found for this sample, indicating the transformation of calcite to anorthite. ${ }^{10}$ The peak at $534.28 \mathrm{~cm}^{-1}$ corresponds to the Fe-O bending of hematite. $^{14}$

\subsection{FE-SEM}

The scanning-electron-microscope observations provided valuable information about the internal morphology, distribution matrix, pore-structure formation and size of the crystals. ${ }^{14}$ This sample contains pores, which are of a medium size, and it is less vitreous in nature, indicating that the temperature, at which the sample was fired was less than $950{ }^{\circ} \mathrm{C} .{ }^{23}$ The presence of feldspar and the accumulation of quartz crystals that are in agreement with the XRD and FT-IR results are shown in Figure 6.

\section{$3.5 \mathrm{XRF}$}

Table 1 lists the XRF-analysis results confirming that the brick sample contains high concentrations of $\mathrm{SiO}_{2}$, $\mathrm{Al}_{2} \mathrm{O}_{3}$ and very low amounts of $\mathrm{Na}_{2} \mathrm{O}, \mathrm{MgO}$ and $\mathrm{CaO}$. Since the amount of calcium present is lower than $6 \%$, the clay used for the manufacturing of bricks was non-calcareous. ${ }^{6,14}$ Since the amounts of inorganic oxides such as $\mathrm{Fe}_{2} \mathrm{O}_{3}, \mathrm{MgO}, \mathrm{CaO}$, etc. are higher than $9 \%$ by weight, they indicate fluxing and a medium refractory property. ${ }^{10}$ The presence of $\mathrm{Na}, \mathrm{Ti}, \mathrm{Ca}, \mathrm{Mg}$ and $\mathrm{K}$ has a non-negligible effect on the hardness of the brick. ${ }^{9}$

Table 1: XRF data

\begin{tabular}{|c|c|}
\hline Oxides & Mass \% \\
\hline $\mathrm{SiO}_{2}$ & 66.9 \\
\hline $\mathrm{Al}_{2} \mathrm{O}_{3}$ & 17.2 \\
\hline $\mathrm{Fe}_{2} \mathrm{O}_{3}$ & 4.3 \\
\hline $\mathrm{CaO}$ & 3.58 \\
\hline $\mathrm{K}_{2} \mathrm{O}$ & 3.13 \\
\hline $\mathrm{Na}_{2} \mathrm{O}$ & 2.12 \\
\hline $\mathrm{MgO}$ & 1.27 \\
\hline $\mathrm{TiO}_{2}$ & 0.748 \\
\hline $\mathrm{P}_{2} \mathrm{O}_{5}$ & 0.297 \\
\hline
\end{tabular}
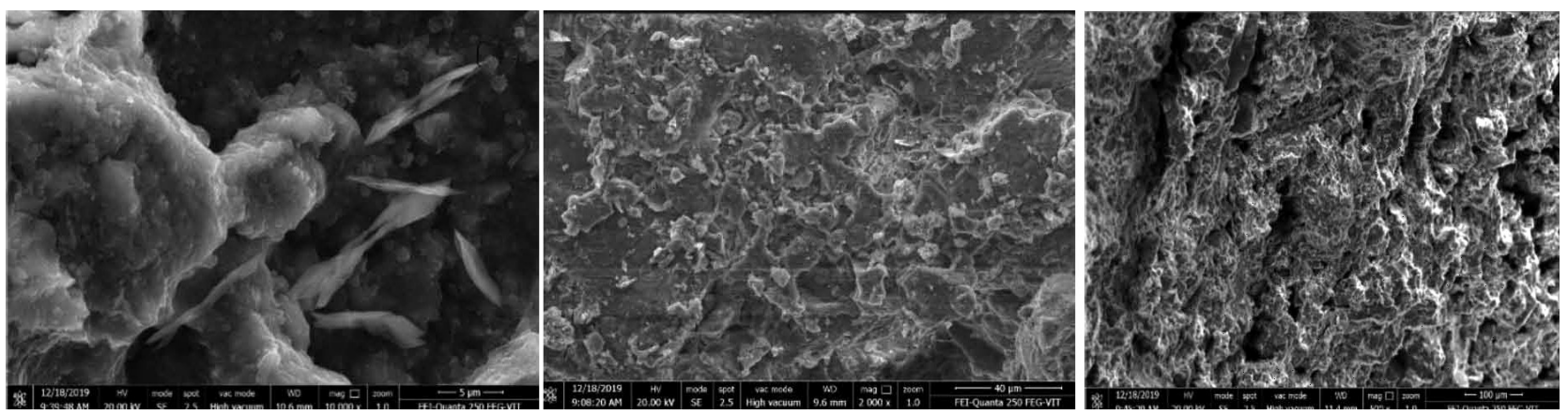

Figure 6: FE-SEM images: a) quartz accumulation; b) feldspar; c) porous structure 


\subsection{TGA}

The TGA curve shown in Figure 7 indicates a negligible weight loss in the region of $600-900{ }^{\circ} \mathrm{C}$, which indicates the dihydroxylation of the raw materials for the brick at the firing temperature, containing a low amount of calcite according to the XRD analysis. ${ }^{6}$ The weight loss of around $1.5 \%$ occurs in the temperature range of $200-400^{\circ} \mathrm{C}$ due to the loss of interlayer water and clay dihydroxylation. ${ }^{2,13}$ The total weight loss is less than $2 \%$ by weight. The firing temperature of the sample is mostly between $750-900{ }^{\circ} \mathrm{C}$. The absence of mullite and cristobalite indicates that the firing temperature is below $950{ }^{\circ} \mathrm{C} .{ }^{6,24}$ The presence of anorthite indicates the decomposition of calcite at higher firing temperatures. ${ }^{2} \mathrm{Be}-$ tween 700 and $800{ }^{\circ} \mathrm{C}$, the clay is of an orange-red color. ${ }^{14}$ DTA (Figure 8) shows the physical changes that do not involve weight changes such as crystallisation, melting, the change in the solid phase and homogeneous reaction in the solid state.

\subsection{OSL}

OSL is a widely used technique in archaeological dating. ${ }^{21}$ The single-aliquot-regeneration (SAR) protocol of Wintle and Murray is used for the determination of the equivalent dose/palaeodose. The amount of the light emitted during the luminescence measurement of the sample depends upon the total radiation dose, to which the crystalline material was exposed while it was buried and it is called the natural signal. This measured signal provides the measure of the palaeodose. The total radiation dose, which a material receives annually is called the annual radiation dose. Based on the OSL dating, the approximate age of the sample is determined to be 2100 years. This test confirms that the well was constructed in the Early historic period.

\subsection{D model}

The modelling of the brick well was based on the principle of photogrammetry, which is a part of $\mathrm{H}-\mathrm{BIM}{ }^{22}$ This is a technology used for obtaining infor-

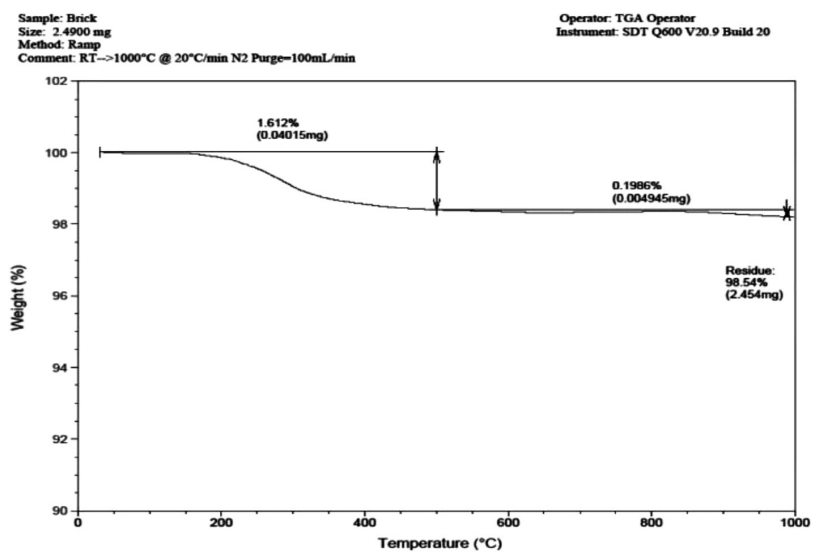

Figure 7: TGA curve of the brick sample

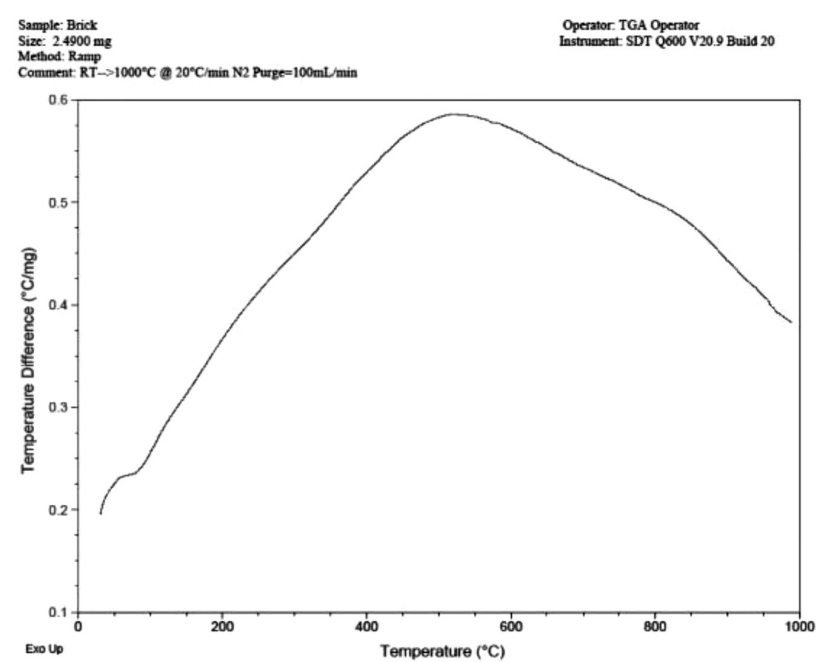

Figure 8: DTA curve of the brick sample

mation about objects through a process of measuring recorded images. The final output is obtained after going through various stages such as the collection of images, archaeological relevance or survey data. The images were captured at an angle of $30^{\circ}$ and stitched together with an overlap of $30^{\circ}$. The rendered $3 \mathrm{D}$ model of the brick well is shown in Figure 9.

\subsection{Physical and mechanical properties}

The water absorption and porosity are the key factors in determining the durability of a brick sample. The water absorption is relatively proportional to the porosity. The value obtained for our sample is $15 \%$; therefore, the sample is durable. The standard water-absorption value must be less than $21 \%$ for high-quality bricks. ${ }^{9}$ The value of porosity obtained is $22.8 \%$ and the bulk density is $1.873 \mathrm{~kg} / \mathrm{m}^{3}$. The compressive strength of the brick obtained is 6.7 MPa. A compressive strength between 2.5 $\mathrm{MPa}$ and $7 \mathrm{MPa}$ is recommended for horizontally perforated bricks used for indoor constructions. ${ }^{10}$ The values are compared with respect to the IS Codes.

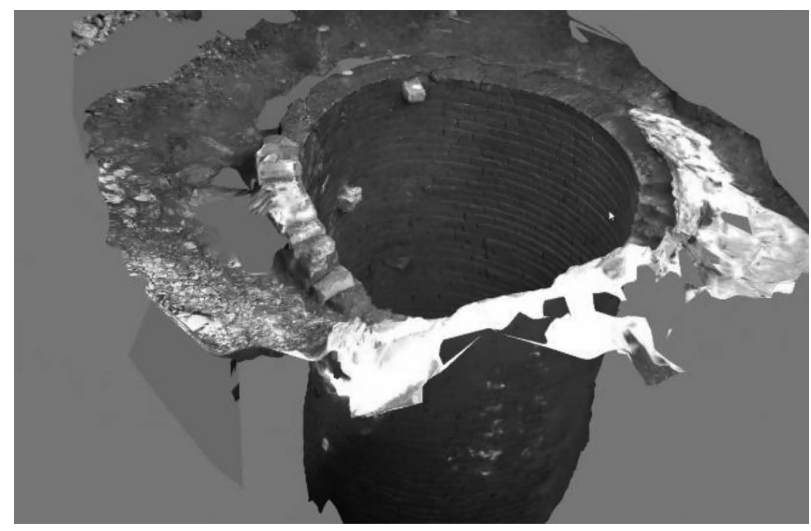

Figure 9: 3D rendering of the Pattaraiperumbudur brick well 


\section{CONCLUSION}

From the tests conducted, it is concluded that the bricks used in the construction of the well exhibit an optimum water absorption, compressive strength and slightly porous structure. The combined results of XRD, OM, SEM, TGA confirm the presence of minerals such as quartz, feldspar, anorthite and boromuscovite. They also provide an idea of the production technology used, indicating that the bricks are non-vitreous in nature and produced from $\mathrm{Ca}$-poor clay with high amounts of silica and alumina at a firing temperature of less than $950{ }^{\circ} \mathrm{C}$. The clay used in the production of exhibits inorganic fluxing and a medium refractory property. The suitable proportion of quartz in the clay prevents shrinkage and warping and improves the durability of bricks. ${ }^{9}$ The OSL dating technique gives the age of the sample, confirming that the brick well was constructed in the Iron Age period.

\section{REFERENCES}

${ }^{1}$ G. Cultrone, I. Sidraba, E. Sebastián, Mineralogical and physical characterization of the bricks used in the construction of the "Triangul Bastion", Riga (Latvia), Applied Clay Science, 28 (2015) 1-4, 297-308, doi:10.1016/j.clay.2004.02.005

${ }^{2}$ P. Cardiano, S. Ioppolo, C. De Stefano, A. Pettignano, S. Sergi, P. Piraino, Study and characterization of the ancient bricks of monastery of "San Filippo di Fragalà" in Frazzanò (Sicily), Analytica Chimica Acta, 519 (2004) 1, 103-111, doi:10.1016/j.aca.2004. 05.042

${ }^{3}$ G. Taglieri, D. Rigaglia, L.Arrizza, V. Daniele, L. Macera, G. Rosatelli, G. Musolino, Microanalytical investigations on a Byzantine fresco of the Dormitio Virginis from Sicily, Journal of Cultural Heritage, 40 (2019), 155-162, doi:10.1016/j.culher.2019. 05.016

${ }^{4}$ M. Secco, C. Previato, A. Addis, G. Zago, A. Kamsteeg, S. Dilaria, J. Bonetto, Mineralogical clustering of the structural mortars from the Sarno Baths, Pompeii: A tool to interpret construction techniques and relative chronologies, Journal of Cultural Heritage, 40 (2019), 265-273, doi:10.1016/j.culher.2019.04.016

${ }^{5}$ A. Coccato, L. Mantovani, R. Ferrari, D. Bersani, M. Tribaudino, P. Lottici, The deposition from the Cross in the church of Saint-Germain-en-Laye (France): A masterpiece of Romanesque sculpture? Materials characterization to solve a 20th c. mystery, Journal of Cultural Heritage, 40 (2019), 133-142, doi:10.1016/ j.culher.2019.05.019

${ }^{6}$ E. U. Sağin, H. Böke, Characteristics of bricks used in the domes of some historic bath buildings, Journal of Cultural Heritage, 14 (2013) 3, e73-e76, doi:10.1016/j.culher.2012.11.030

${ }^{7}$ A. Moropoulou, A. Bakolas, K. Bisbikou, Characterization of ancient, byzantine and later historic mortars by thermal and X-ray diffraction techniques, Thermochimica Acta, 269 (1995), 779-795, doi:10.1016/0040-6031(95)02571-5

${ }^{8}$ M. Taranto, L. Barba, J. Blancas, A. Bloise, M. Cappa, F. Chiaravalloti, M. Lezzerini, The bricks of Hagia Sophia (Istanbul, Turkey): A new hypothesis to explain their compositional difference, Journal of Cultural Heritage, 38 (2019), 136-146, doi:10.1016/j.culher. 2019.02.009
${ }^{9}$ T. Monatshebe, A. F. Mulaba-Bafubiandi, D. K. Nyembwe, Mechanical properties and mineralogy of artisanal clay bricks manufactured in Dididi, Limpopo, South Africa, Construction and Building Materials, 225 (2019), 972-982, doi:10.1016/j.conbuildmat.2019.07.247

${ }^{10}$ A. N. Adazabra, G. Viruthagiri, N. Shanmugam, Infrared analysis of clay bricks incorporated with spent shea waste from the shea butter industry, Journal of environmental management, 191 (2017), 66-74, doi:10.1016/j.jenvman.2017.01.006

${ }^{11}$ Y. T. Xu, B. Yang, X. M. Liu, S. Gao, D. S. Li, E. Mukiza, H. J. Li, Investigation of the medium calcium based non-burnt brick made by red mud and fly ash: durability and hydration characteristics, International Journal of Minerals, Metallurgy, and Materials, 26 (2019) 8, 983-991, doi.org/10.1007/s12613-019-1814-9

${ }^{12}$ L. Paama, I. Pitkãnen, P. Perämäki, Analysis of archaeological samples and local clays using ICP-AES, TG-DTG and FTIR techniques, Talanta, 51 (2000) 2, 349-357, doi:10.1016/S0039-9140(99)00281-7

${ }^{13}$ D. Seetha G. Velraj, Characterization and chemometric analysis of ancient pot shards trenched from Arpakkam, Tamil Nadu, India, Journal of applied research and technology, 14 (2016) 5, 345-353, doi:10.1016/j.jart.2016.08.002

${ }^{14}$ P. B. Lourenço, F. M. Fernandes, F. Castro, Handmade clay bricks: chemical, physical and mechanical properties, International Journal of Architectural Heritage, 4 (2010) 1, 38-58, doi:10.1080/ 15583050902871092

${ }^{15}$ M. R. Sheikh, A. G. Barua, X-ray diffraction and Fourier transform infrared spectra of the bricks of the Kamakhya temple, Indian Journal of Pure \& Applied Sciences, 51 (2013), 745-748

${ }^{16}$ E. Aquilia, G. Barone, P. Mazzoleni, S. Raneri, G. Lamagna, Petro-archaeometric characterization of potteries from a kiln in Adrano, Sicily, Heritage Science, 3 (2015) 1, 11, doi:10.1186/ s40494-015-0043-4

${ }^{17}$ C. Oguz, F. Turker, N. U. Kockal, Construction materials used in the historical Roman era bath in Myra, The Scientific World Journal, (2014), doi:10.1155/2014/536105

${ }^{18}$ D. M. Freire-Lista, G. Kahraman, R. Carter, Multi-Analysis Characterisation of a Vernacular House in Doha (Qatar): Petrography and Petrophysics of its Construction Materials, Minerals, 9 (2019) 4, 241, doi:10.3390/min9040241

${ }^{19}$ I. S. de Soto García, M. D. L. de Soto García, R. García Giménez, Mineralogical analysis of mortars in the walls of Avila (Spain) and its surroundings, Minerals, 9 (2019) 6, 381, doi:10.3390/min9060381

${ }^{20}$ F. Kharfi, L. Boudraa, I. Benabdelghani, M. Bououden, TL dating and XRF clay provenance analysis of ancient brick at Cuicul Roman city, Algeria, Journal of Radioanalytical and Nuclear Chemistry, 320 (2019) 2, 395-403, doi:10.1007/s10967-019-06491-z

${ }^{21}$ L. M. Khodeir, D. Aly, S. Tarek, Integrating HBIM (Heritage Building Information Modeling) tools in the application of sustainable retrofitting of heritage buildings in Egypt, Procedia Environmental Sciences, 34 (2016), 258-270, doi:10.1016/j.proenv.2016.04.024

${ }^{22}$ A. M. Altay, T. Koralay, E. Sahiner, Luminescence dating and mineralogical investigations of bricks from Erikli Basilica in Stratonikeia ancient city (SW-Turkey), Mediterranean Archaeology and Archaeometry 18 (2018) 1, 77-91, doi:10.5281/zenodo.1069527

${ }^{23}$ G. A Duller, Luminescence Dating: guidelines on using luminescence dating in archaeology, English Heritage, 2008

${ }^{24}$ H. Böke, S. Akkurt, B. Ipekoğlu, E. Uğurlu, Characteristics of brick used as aggregate in historic brick- lime mortars and plasters, Cement and Concrete Research, 36 (2006), 1115-1122, doi:10.1016/ j.cemconres.2006.03.011

${ }^{25}$ M. M. Raith, P. Raase, G. Reinhardt, Guide to Thin Section Microscopy, $2^{\text {nd }}$ edition, University of Bonn, 2011 